\title{
Experimental Study of Enhancing the Shear Strength of Hidden/Shallow Beams by Using Shear Reinforcement
}

\author{
Nohaira S. Morsy, Alaa G. Sherif, Ata E. Shoeib, Mohamed H. Agamy \\ Faculty of Engineering, Mataria, Helwan University \\ Cairo, Egypt \\ atta_alsayed@m-eng.helwan.edu.eg, ataelkareim_2008@yahoo.com
}

\begin{abstract}
The primary objective of this article is to study the effect of shear reinforcement on the performance of wide shallow beams. The investigated parameters include the crack patterns, mode of failures, load-deflection curves, load-strain curves of stirrups and the failure load. Nine tested specimens have $1800 \mathrm{~mm}$ clear span and $500 \mathrm{~mm}$ width with different thicknesses $(150 \mathrm{~mm}, 200 \mathrm{~mm}$, and $250 \mathrm{~mm}$ ), and type of the web reinforcement. The experimental results showed that there was a significant improvement in the shear strength due to using the traditional tied stirrups for beams with depth $250 \mathrm{~mm}$, but it seems that the vertical tied reinforcement does not work properly to resist the shear for beams with depth less than $250 \mathrm{~mm}$. While the welded link web reinforcement increases the shear capacity for beams with depth less than $250 \mathrm{~mm}$. A comparison between experimental shear capacities and the prediction of the ECP-203-2016, ACI 318-14, EN1992 and CSA 2004 codes are also presented in this research. It is recommended to re-evaluate the contribution of the shear reinforcement according to the Egyptian ECP-203. In addition, the tested beams specimens are analysed using the nonlinear finite element method (ANSYS). The results showed that the effect of web reinforcement on improving shear strength is more pronounced at higher depth of specimens.
\end{abstract}

Keywords: Shallow Wide Beam, Shear Reinforcement, Welded Link Stirrups.

\section{Introduction}

In the design of buildings, modern architectural constraints are pushing engineers to provide longer clear spans at a reasonable cost. At the same time, there is a need to minimize the overall structural depth, which can be achieved through the use of wide beams or thick structural slabs. Wide shallow beams in concrete buildings are usually constructed as hidden beams in the sense that these wide beams have the same depth as the supported floor. The wide beams may be used to carry direct forces or to serve as primary transfer elements. However, the shear failure in reinforced concrete structures is highly brittle when compared with the flexural failure [1-5]. According to the Egyptian Code of practice (ECP 2032016) [6], in case of beams with a total depth not greater than 250mm, 2.5 times thickness of flange, or half of the width of web, whichever is greatest, the shear stresses must be less than the concrete shear strength with no consideration of the contribution of shear reinforcement. As a consequence large cross-sectional areas of concrete have to be provided to meet one-way shear demands. While the code neglects the web reinforcement contribution in the shear strength, in practice a minimum web reinforcement is provided. These requirements of the code lead to a very conservative, uneconomic shear design of shallow wide beams. The target of this study was to investigate the effectiveness of shear reinforcement in increasing the shear strength of shallow wide beams by using different types of stirrups at different shear span-to-depth ratios $(\mathrm{a} / \mathrm{d})$.

\section{Experimental Program}

To investigate the effect of using different types of stirrups to enhance the shear capacity of reinforced concrete RC shallow wide beams and evaluate the allowable shear force with the shear reinforcement contribution, an experimental program consisting of eight simply supported RC shallow wide beams is conducted. The tested specimens have $500 \mathrm{~mm}$ width, and $2000 \mathrm{~mm}$ length with different thickness $(150 \mathrm{~mm}, 200 \mathrm{~mm}$ and $250 \mathrm{~mm})$ as shown in Table 1 . All tested specimens have longitudinal reinforcement $10 \emptyset 16$ bottom, and $4 \emptyset 12$ top steel bars. The stirrups used are $5 \emptyset 8 /$ meter with different configurations. All tested specimens were designed to fail in shear. The average concrete cube compressive 
strength of the concrete used in the cast of the tested specimens is shown in Table 1. The yield strength of top and bottom longitudinal steel, and vertical stirrups were equal to 360MPa, and $240 \mathrm{MPa}$ respectively.

Two types of stirrups were used as shown in Table 2. The first group of beams did not contain stirrups, the second group contained traditional stirrups (four branches), while the third group contained four link stirrups welded with the top and bottom longitudinal reinforcement.

Table 1: The results of the tested specimens.

\begin{tabular}{|c|c|c|c|c|c|c|c|c|c|c|c|c|c|}
\hline 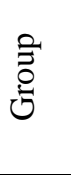 & 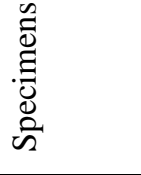 & 离 & 苍苍 & 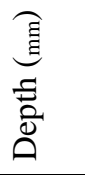 & 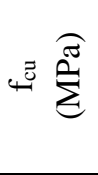 & $a^{0} \overline{\underline{z}}$ & 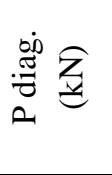 & 总 & 氞 & 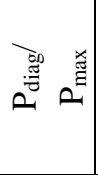 & 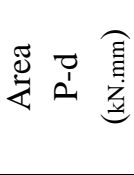 & 岕 & $\mid \begin{array}{ll}\frac{4}{0} & 0 \\
\frac{0}{0} & 0 \\
0 & 0 \\
0 & 0\end{array}$ \\
\hline \multirow[t]{2}{*}{ G1 } & HBC 25 & 250 & None & 250 & 33.79 & 147.62 & 211.87 & 264.93 & 0.56 & 0.80 & 1938.8 & 4.38 & 1.00 \\
\hline & HBS 25 & 250 & Traditional & 250 & 28.04 & 131.79 & 239.58 & 345.26 & 0.38 & 0.69 & 3840.7 & 5.30 & 1.21 \\
\hline \multirow[t]{3}{*}{$\mathrm{G} 2$} & HBC 20 & 200 & none & 200 & 33.79 & 163.6 & 189.60 & 239.30 & 0.68 & 0.79 & 2131.6 & 4.27 & 1.00 \\
\hline & HBS 20 & 200 & Traditional & 200 & 28.04 & 115.5 & 199.6 & 243.20 & 0.47 & 0.82 & 3018.7 & 5.38 & 1.26 \\
\hline & HBA 20 & 200 & weld & 200 & 33.43 & 111.3 & 203.90 & 317.50 & 0.35 & 0.64 & 3282.8 & 10.8 & 2.52 \\
\hline \multirow[t]{3}{*}{ G3 } & HBC 15 & 150 & none & 150 & 33.79 & 93.9 & 139.20 & 178.20 & 0.53 & 0.78 & 1931.8 & 6.4 & 1.00 \\
\hline & HBS 15 & 150 & Traditional & 150 & 28.04 & 117.2 & 162.00 & 194.80 & 0.60 & 0.83 & 1333.2 & 7.6 & 1.19 \\
\hline & HBA 15 & 150 & weld & 150 & 33.43 & 118.2 & 172.70 & 225.00 & 0.53 & 0.77 & 3240.7 & 10.44 & 1.63 \\
\hline
\end{tabular}

Table 2: Type of stirrups.

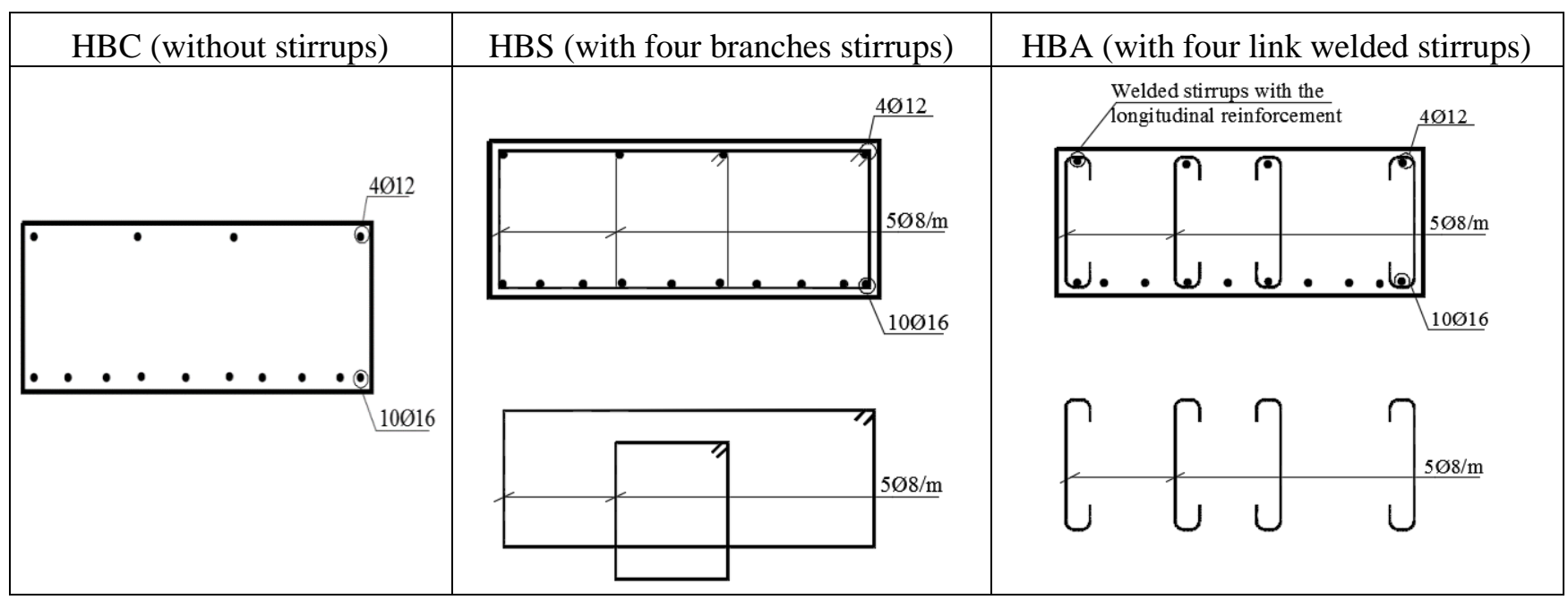

The eight tested specimens are divided into three groups with the different studied parameters. In the first group, the two tested specimens named "HBC25" and "HBS25" with and with without stirrups, were tested to study the effect of stirrups contribution in tested beams with the $250 \mathrm{~mm}$ thickness in shear strength. In the second group, the three tested specimens with the 200mm thickness named "HBC20", "HBS20" and "HBA20" presented the three types of stirrups used to study the effect of type of stirrups in enhancing the shear strength. In the third group, the three tested specimens with 150mm thickness named "HBC15", "HBS15" and "HBA15" presented the three types of stirrups used to study the effect of type of stirrups in enhancing the shear strength. 
The beams were tested using a hydraulic jack with $1000 \mathrm{kN}$ capacity, manually operated by an oil pump. The test setup and instrumentation used are shown in Figure 1. An electrical load cell (accuracy of $0.1 \mathrm{kN}$ ) connected to a digital load indicator is used to measure the applied vertical loads. The deflection of the tested beams was recorded using three electric dial gauges LVDT, one at mid-span, and the second, and the third located at quarter-span from each support of the tested beam located at the bottom face of the beam supports. The strain of the main steel reinforcement and the first stirrups beside support were measured using two strain gauges. The three electric dial gauges, two electric strain gauges, load cell were connected to the data acquisition system attached to the computer. Continuous recording of the load, displacements, and reinforcement strains were provided throughout each test beam up to failure.

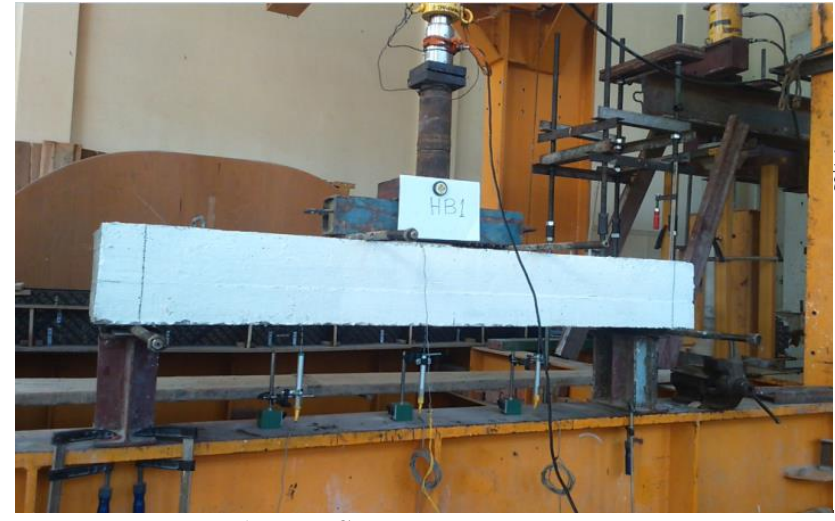

a) Test Set-up

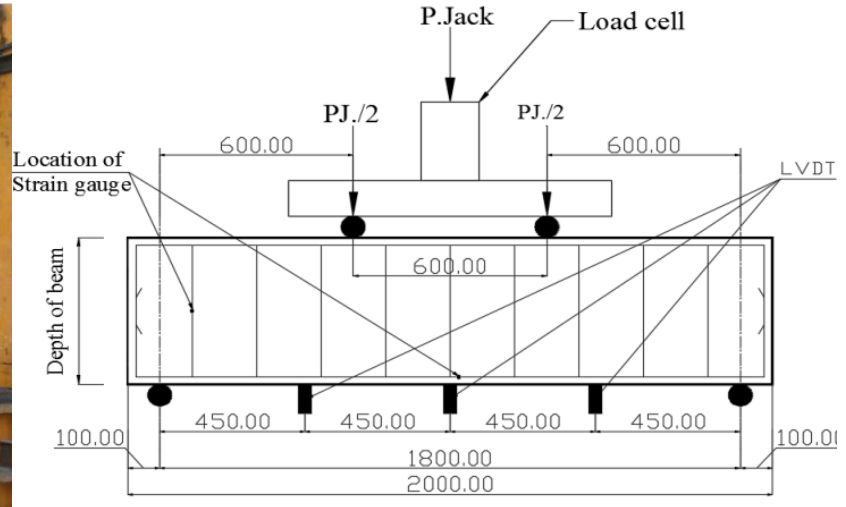

b) Schematic of test Set-up

Fig. 1: Test set-up and instrumentation of tested specimens.

\section{Test Results and Analysis}

\subsection{Crack Pattern and Mode of Failure}

The crack patterns for all tested specimens are shown in Figure 2. In general, it was observed that the first crack $\left(\mathrm{P}_{\mathrm{cr}}\right)$ was a vertical flexural crack occurring near mid span. After that, additional diagonal shear cracks appeared and propagated towards the top compression flange or the bottom and continued propagating horizontally. The first diagonal cracking load ( $\left.\mathrm{P}_{\text {diag. }}\right)$ and maximum failure load $\left(\mathrm{P}_{\max }\right)$ are listed in Table 1. The cracking loads ranged from $35 \%$ to $68 \%$ of the maximum loads, while the diagonal cracks appeared at loads ranging from $64 \%$ to $83 \%$ of the maximum failure loads. By comparing between traditional stirrups and welded stirrups, it was found that the welded type did not effect on the cracking load. However, the diagonal cracking loads were slightly delayed and the maximum failure loads increased. 


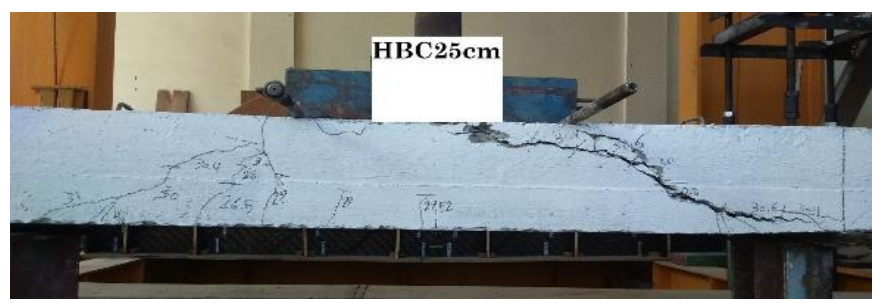

a) $\mathrm{HBC} 25$

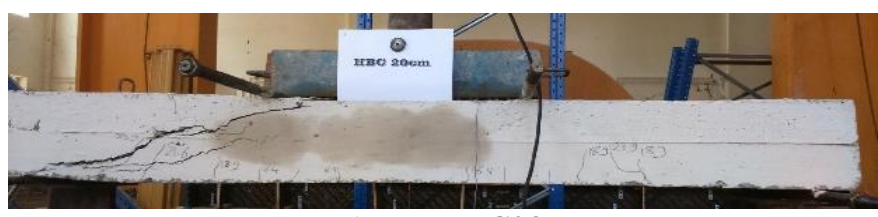

c) $\mathrm{HBC} 20$

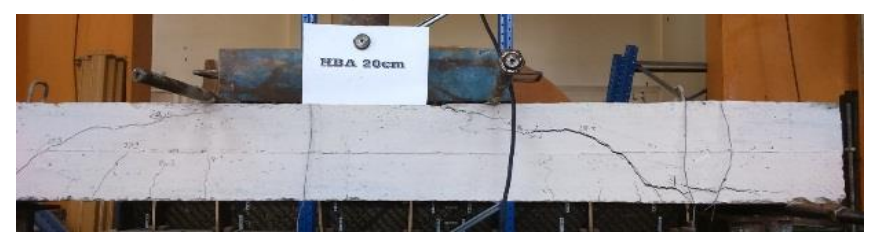

e) HBA20

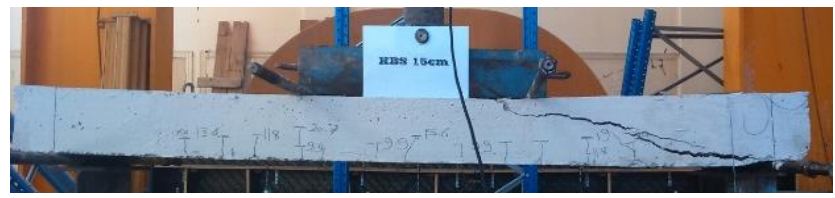

g) $\mathrm{HBS} 15$

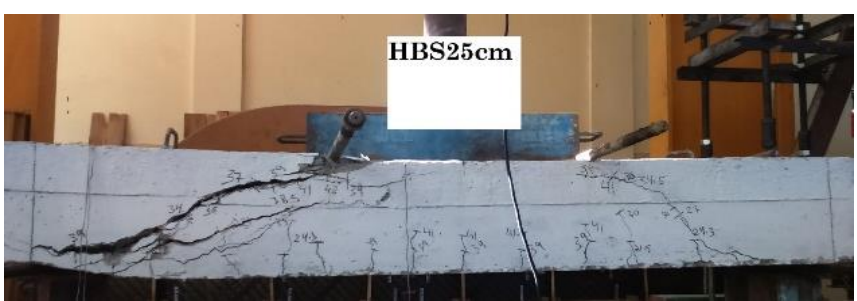

b) HBS25

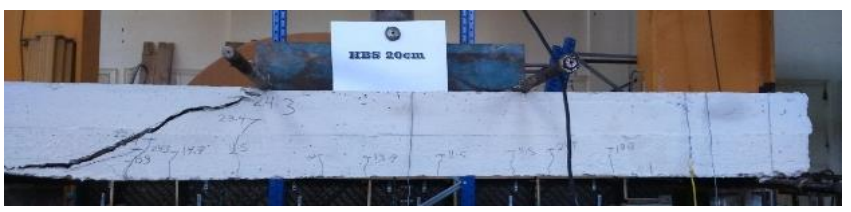

d) $\mathrm{HBS} 20$

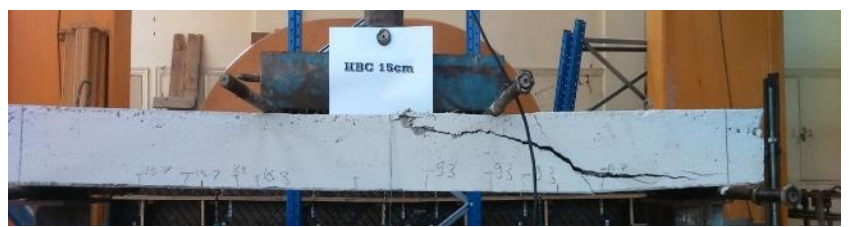

f) $\mathrm{HBC} 15$

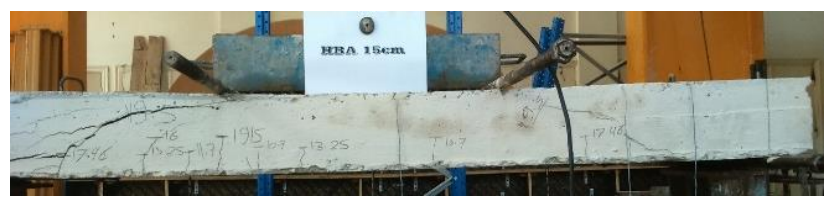

h) HBA15

Fig. 2: The crack pattern of tested specimens.

\subsection{Load Deflection Curves}

The load deflection curves measured at the mid-span are shown in Figure 3. In general, using stirrups increases the maximum failure load of the tested specimens and enhances the behaviour.

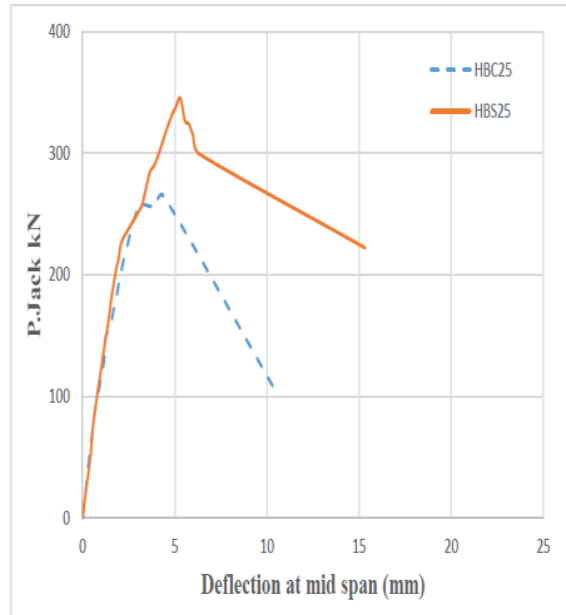

thickness $=250 \mathrm{~mm}$

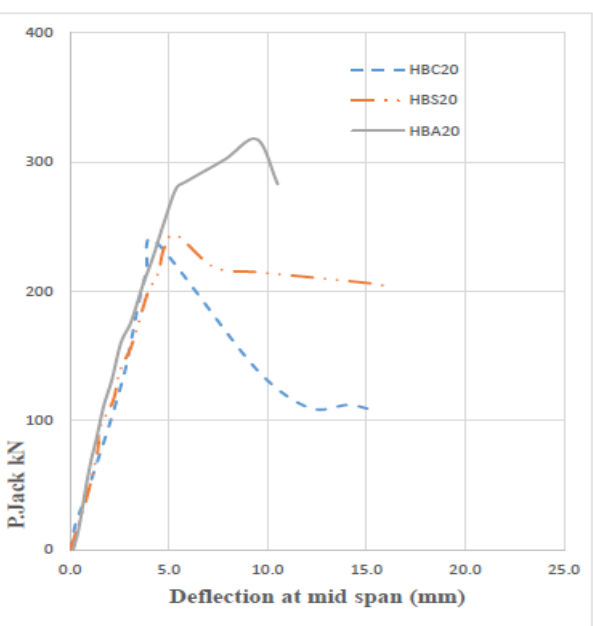

b) thickness $=200 \mathrm{~mm}$

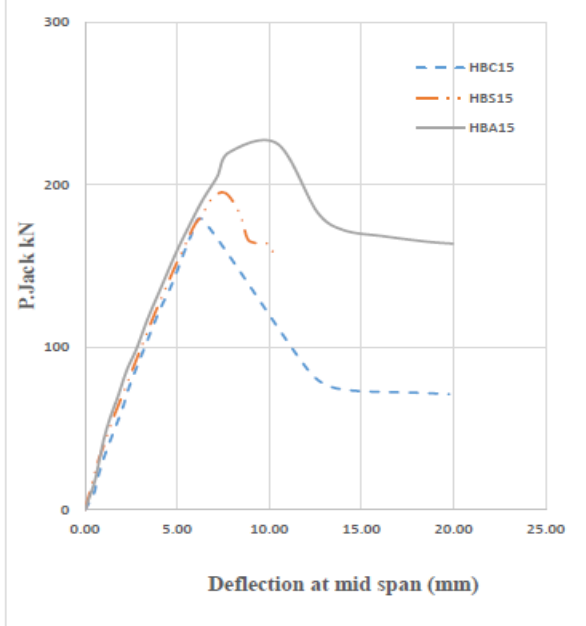

b) thickness $=150 \mathrm{~mm}$

Fig. 3: The effect of type of stirrups on the load deflection curves at different beam thickness. 
As shown in Table 1, for the shallow wide beams of $250 \mathrm{~mm}, 200 \mathrm{~mm}$, and 150 thickness, the traditional stirrups with four branches increased the maximum load by about $30.0 \%, 2.0 \%$ and $9.0 \%$ compared to the control beam without stirrups. On the other hand, for the shallow beams with $200 \mathrm{~mm}$ and 150 thicknesses, the welded link stirrups increased the maximum loads by about $33 \%$, and $26.0 \%$ compared to the control beam without stirrups respectively. From this it can be concluded that using weld stirrups significantly increases the shear resistance of the shallow wide RC beams. By comparing between using traditional stirrups, and welded stirrups it can be concluded that the welded stirrups are much more efficient than the traditional stirrups for the beams with thicknesses $150 \mathrm{~mm}$ and $200 \mathrm{~mm}$. By calculating the energy absorption (the area under load-deflection curves) as shown in Table 1 it can also be concluded that the energy absorption increases by using traditional stirrups and even more increases if welded stirrups are used.

\subsection{The Effect of Shear Span-To-Depth Ratio (A/D)}

The inclination of the diagonal cracks depended on the shear span to depth ratio as the angle decreased with increasing span-to-depth ratio $(\mathrm{a} / \mathrm{d})$. Figure 4 shows the relation between stress and deflection taking the effect of the thickness of tested specimens into consideration.
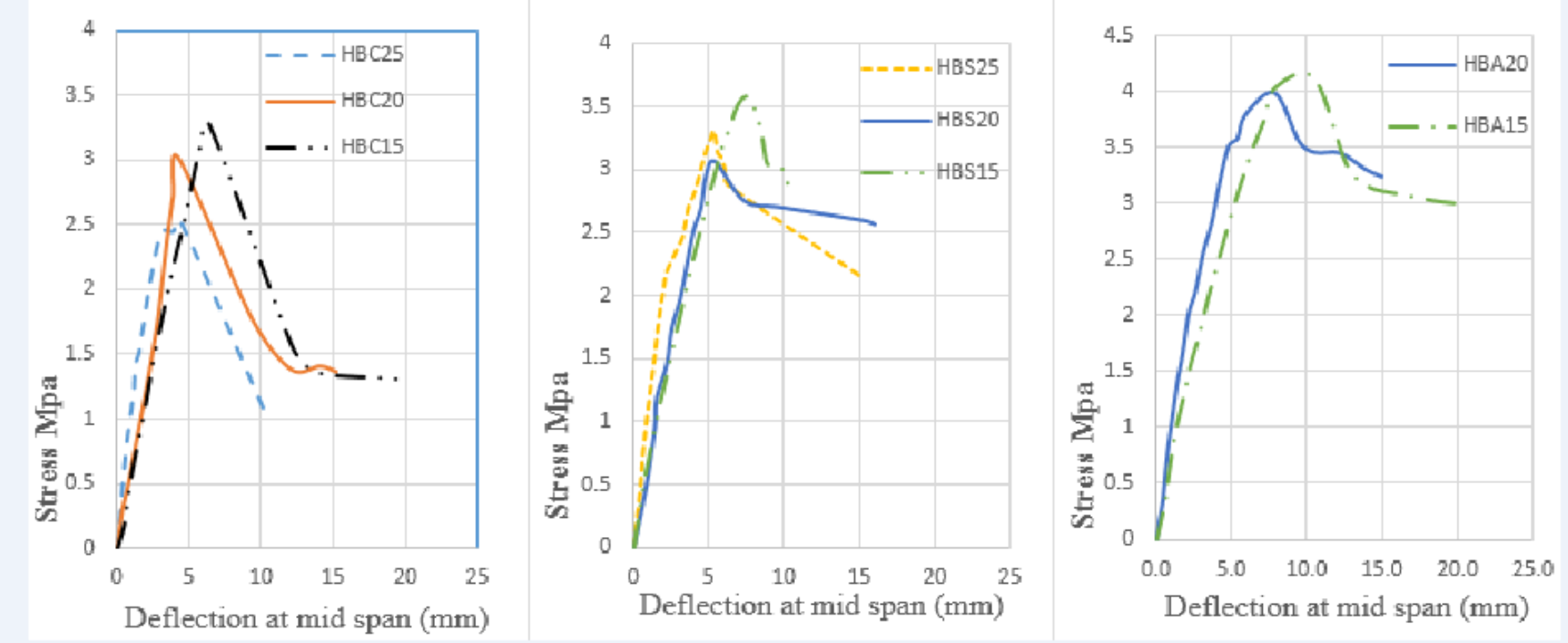

Fig. 4: The effect of variation thickness of tested beam on the load-deflection curve.

\subsection{Load Strain Curves}

The load-strain curves of steel bars at the mid-span section is shown in Figure 5. The strains of the main steel bars are larger in tested specimens without stirrups compared to the tested specimens with stirrups at the same loads except group1. The welding of the stirrups resulted in earlier yielding compared to the traditional stirrups. 


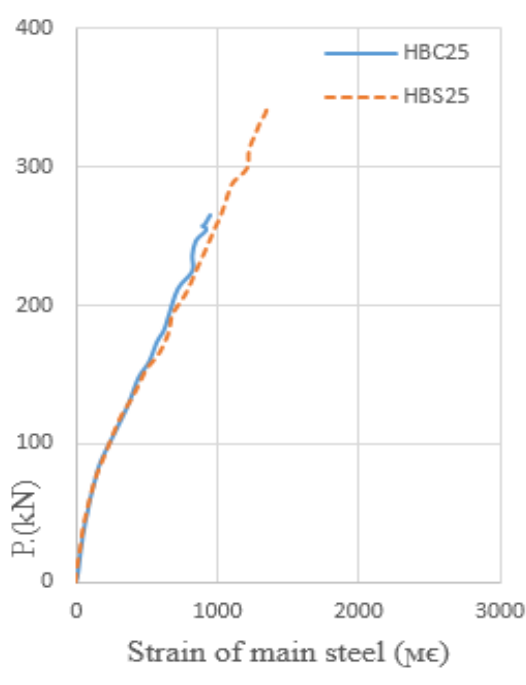

a) thickness $=250 \mathrm{~mm}$

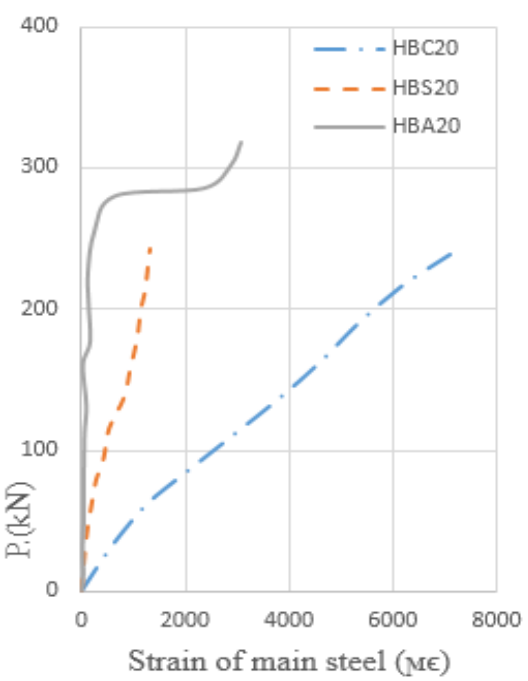

b) thickness $=200 \mathrm{~mm}$

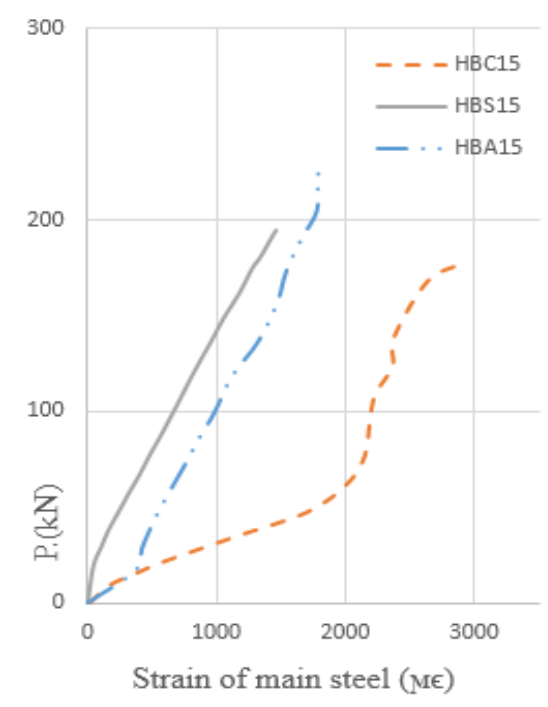

c) thickness $=150 \mathrm{~mm}$

Fig. 5: The effect of variation thickness of tested beam on the load-strain curves of the steel bar at the mid-span section.

\section{Comparing Between Experimental Results and Analytical Ultimate Load of Different Codes}

\subsection{The Shear Capacity of Shallow Wide RC Beams without Shear Stirrups}

According to ECP 203-2011 [6], ACI 318-14 [7], EN1992 [8], and CSA 2004 [9], the concrete contribution in the shear resistance is calculated by Eqs. 1, 2, 3 and 4 respectively.

$$
\begin{aligned}
& \mathrm{V}_{\mathrm{c}}=\mathrm{bd} \times\left[0.16 \times \sqrt{\frac{\mathrm{f}_{\mathrm{cu}}}{\gamma_{\mathrm{c}}}}\right] \\
& \mathrm{V}_{\mathrm{c}}=\mathrm{bd} \times\left[0.17 \times \sqrt{\mathrm{f}^{\prime}}{ }_{\mathrm{c}}\right]
\end{aligned}
$$

where $f_{c u}$ is the concrete cube compressive strength at 28 day, and $f_{c}^{\prime}$ is the concrete cylinder compressive strength after 28day

$$
\begin{gathered}
\mathrm{V}_{\mathrm{c}}=\mathrm{bd} \times\left[0 \frac{0.18}{\gamma_{\mathrm{c}}} \mathrm{k}\left(100 \times \rho_{1} \times \mathrm{f}_{\mathrm{ck}}\right)^{1 / 3}\right] \geq 0.035 \mathrm{k}^{2 / 3} \mathrm{f}_{\mathrm{ck}}^{0.5} \\
\left.\mathrm{~V}_{\mathrm{c}}=\mathrm{bd} \times \mid \beta \times \sqrt{\mathrm{f}_{\mathrm{c}}^{\prime}}\right]
\end{gathered}
$$

Where $f_{\mathrm{ck}}=$ characteristic concrete cube strengthMPa); $\mathrm{k}=1+\sqrt{\frac{200}{d}} \leq 2 ; \rho=\frac{A s l}{b * d} \leq 0: \beta=$ factor indicating the ability of diagonally cracked concrete to transmit tension; $f_{\mathrm{c}}$ is the concrete cylinder compressive strength after 28 day. 
Table 3 includes a comparison between the experimental shear force and allowable shear force calculated according to the different codes. All investigated codes give conservative values for the failure loads. EN-1992 is the most accurate in predicting the experimental failure loads because it accounts for the size effect (thickness) of the tested beams.

Table 3: Comparison between the experimental and code failure shear for beams without stirrups.

\begin{tabular}{|c|c|c|c|c|c|c|c|c|c|}
\hline \multirow{3}{*}{$\begin{array}{l}0 \\
0 \\
0 \\
0 \\
0 \\
\tilde{0}\end{array}$} & \multirow{2}{*}{$\begin{array}{l}\text { Experimental } \\
\text { shear capacity }\end{array}$} & \multicolumn{8}{|c|}{ Predicted Shear Capacity "V $\mathrm{V}_{\text {code." }}(\mathrm{kN})$} \\
\hline & & \multicolumn{2}{|c|}{ ECP203-2011 } & \multicolumn{2}{|c|}{ ACI 318-14 } & \multicolumn{2}{|c|}{ EN-1992 } & \multicolumn{2}{|c|}{ CSA-2004 } \\
\hline & $\mathrm{V}_{\text {exp. }}(\mathrm{kN})$ & $\begin{array}{l}\mathrm{V}_{\text {code }} \\
(\mathrm{kN})\end{array}$ & $\begin{array}{l}\mathrm{V}_{\text {exp. }} / \\
\mathrm{V}_{\text {code }}\end{array}$ & $\begin{array}{l}\mathrm{V}_{\text {code }} \\
(\mathrm{kN})\end{array}$ & $\begin{array}{l}V_{\text {exp }} / \\
V_{\text {code }}\end{array}$ & $\begin{array}{l}\mathrm{V}_{\text {code }} \\
(\mathrm{kN})\end{array}$ & $\begin{array}{l}\mathrm{V}_{\text {exp. }} / \\
\mathrm{V}_{\text {code }}\end{array}$ & $\begin{array}{l}\mathrm{V}_{\text {code }} \\
(\mathrm{kN})\end{array}$ & $\begin{array}{l}\mathrm{V}_{\text {exp }} / \\
\mathrm{V}_{\text {code }}\end{array}$ \\
\hline HBC 25 & 132.47 & 104.65 & 1.27 & 99.45 & 1.33 & 143.10 & 0.93 & 110.56 & 1.20 \\
\hline HBC 20 & 119.65 & 81.40 & 1.47 & 77.34 & 1.55 & 119.10 & 1.00 & 86.00 & 1.39 \\
\hline HBC 15 & 98.10 & 58.13 & 1.69 & 55.24 & 1.78 & 85.10 & 1.15 & 61.40 & 1.60 \\
\hline
\end{tabular}

\subsection{The Shear Capacity of Shallow Wide RC Beam with Shear Stirrups}

ECP 203-2011 [6] neglects the effect of vertical stirrups for RC beam with depth less than 250mm. ACI 318-14 [7], CSA 2004 [9], and EN1992 [8] accounts for the contribution of the shear reinforcement by Eqs. 5, 6 and 7 respectively.

$$
\begin{aligned}
& V_{s}=\frac{A_{s t} \times f_{y} / \gamma_{s} \times d}{s} \\
& V_{s}=\frac{A_{v} f_{y} d_{v} \times \cot \theta}{S}
\end{aligned}
$$

$A_{s t}$, or $A_{v}=$ area of shear reinforcement $\left(\mathrm{mm}^{2}\right) ; \quad \Theta=$ Angle of inclination of the diagonal compressive struts;

$$
\mathrm{V}_{\mathrm{RD}}=\mathrm{V}_{\mathrm{RD}, \mathrm{s}}=\frac{\mathrm{A}_{\mathrm{sw}}}{\mathrm{S}} \times \mathrm{Z} \times \mathrm{f}_{\mathrm{ywd}} \times \cot \theta \leq \mathrm{V}_{\mathrm{RD} \max }=\frac{\alpha \times \mathrm{v}_{1} \times \mathrm{f}_{\mathrm{cd}}}{\cot \theta+\tan \theta} \times \mathrm{b} \times \mathrm{Z}
$$

$A_{\mathrm{sw}}=$ cross-sectional area of the shear reinforcement (mm2), $\mathrm{S}=$ spacing of the stirrups $(\mathrm{mm}) ; \mathrm{f}_{\mathrm{ywd}}=$ yield strength of the shear reinforcement (MPa) for vertical shear reinforcement; $\Theta=$ angle between compression strut and the longitudinal axis; equal to $45^{\circ} ; \mathrm{z}=$ the inner lever arm for a member with constant depth $(\mathrm{mm})$.

A comparison between experimental and numerical shear resistance calculated by ECP 203-2011 [6], ACI 318-14 [7], EN1992 [8], and CSA 2004 [9], is presented in Table 4, taken into consideration the stirrups contribution in the shear resistance.

As shown in Table 4, all investigated codes give conservative results. In addition, the ratio between the experimental shear force and calculated by ECP-203 considering the vertical stirrups contribution ranges from 1.35 to 1.62. 
Table 4: Comparison between the experimental shear forces with stirrups and predicted by different codes.

\begin{tabular}{|c|c|c|c|c|c|c|c|c|c|}
\hline \multirow{3}{*}{ 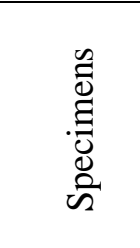 } & \multirow{3}{*}{$\begin{array}{c}\text { Experiment } \\
\text { al shear } \\
\text { capacity } \\
\mathrm{V}_{\text {exp. }}(\mathrm{kN})\end{array}$} & \multicolumn{8}{|c|}{ Predicted Shear Capacity "V code." $_{\text {(kN) }}$} \\
\hline & & \multicolumn{2}{|c|}{ ECP203-2011 } & \multicolumn{2}{|c|}{ ACI $318-14$} & \multicolumn{2}{|c|}{ EN-1992 } & \multicolumn{2}{|c|}{ CSA-2004 } \\
\hline & & $\begin{array}{l}\mathrm{V}_{\text {code }} \\
(\mathrm{kN})\end{array}$ & $\begin{array}{l}\mathrm{V}_{\text {exp. }} / \\
\mathrm{V}_{\text {code }}\end{array}$ & $\begin{array}{l}\mathrm{V}_{\text {code }} \\
(\mathrm{kN})\end{array}$ & $\begin{array}{l}\mathrm{V}_{\text {exp }} / \\
\mathrm{V}_{\text {code }}\end{array}$ & $\begin{array}{l}\mathrm{V}_{\text {code }} \\
(\mathrm{kN})\end{array}$ & $\begin{array}{l}\mathrm{V}_{\text {exp. }} / \\
\mathrm{V}_{\text {code }}\end{array}$ & $\begin{array}{l}\mathrm{V}_{\text {code }} \\
(\mathrm{kN})\end{array}$ & $\begin{array}{l}\mathrm{V}_{\text {exp. }} / \\
\mathrm{V}_{\text {code }}\end{array}$ \\
\hline HBS 25 & 172.63 & 98.05 & 1.76 & 147.50 & 1.55 & 48.89 & 3.53 & 158.00 & 1.09 \\
\hline HBS 20 & 121.60 & 74.20 & 1.64 & 112.70 & 1.08 & 38.03 & 3.20 & 120.56 & 1.01 \\
\hline HBA 20 & 158.75 & 80.95 & 1.96 & 119.20 & 1.33 & 38.03 & 4.17 & 127.75 & 1.24 \\
\hline HBS 15 & 97.40 & 53.00 & 1.84 & 80.50 & 1.21 & 27.16 & 3.59 & 86.11 & 1.13 \\
\hline HBA 15 & 112.50 & 57.82 & 1.95 & 85.13 & 1.32 & 27.16 & 4.14 & 91.25 & 1.23 \\
\hline
\end{tabular}

\section{Theoretical Study Using Finite Element Program (ANSYS)}

The nonlinear finite element method (ANSYS) is used to study the effect of increased shear reinforcement with welded links stirrups. A solid element, SOLID65, Link 180, and SOLID185 is used for concrete, reinforcement steel bars, and element used for steel plate respectively to model the beam in ANSYS, as shown in Figure 5.

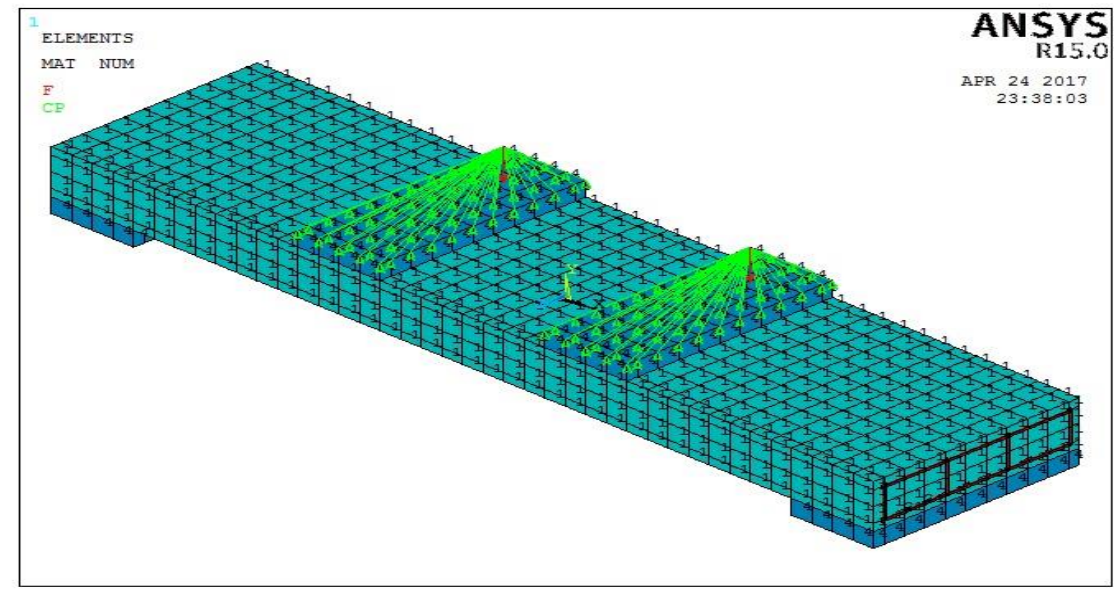

Fig. 5: Modelling of the tested specimen.

The verification is carried out on the experimental control tested specimen in order to check the validity and accuracy of the finite element model with different factors. For all theoretical specimens, the bond between the concrete and steel reinforcing is assumed to be perfect in the finite element models.

The theoretical results show that the crack patterns detected in the ANSYS models is quite similar to the experimental ones. The load-deflection curves of the theoretical tested specimens and experimental specimens HBA15 and HBA 20 are shown in Figure 6. The results shown that the theoretical stiffness is more than the experimental stiffness. 


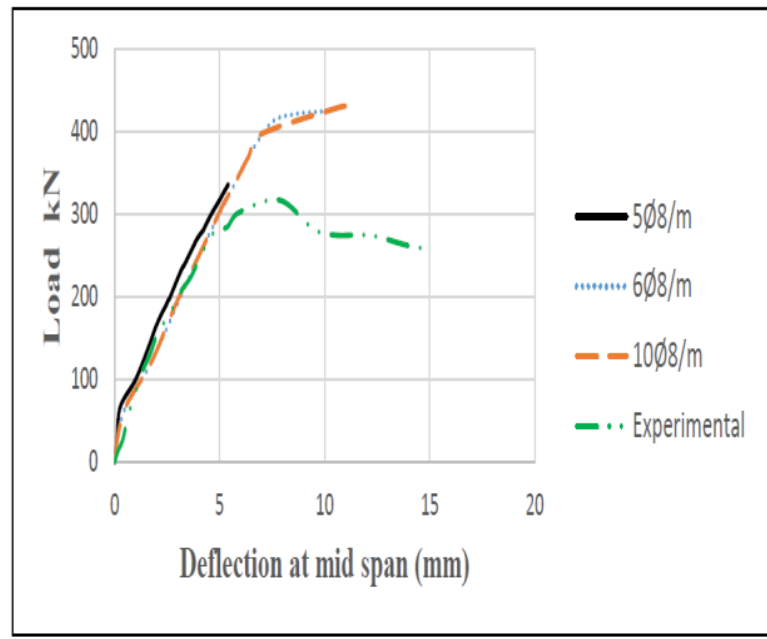

a) Depth $200 \mathrm{~mm}$

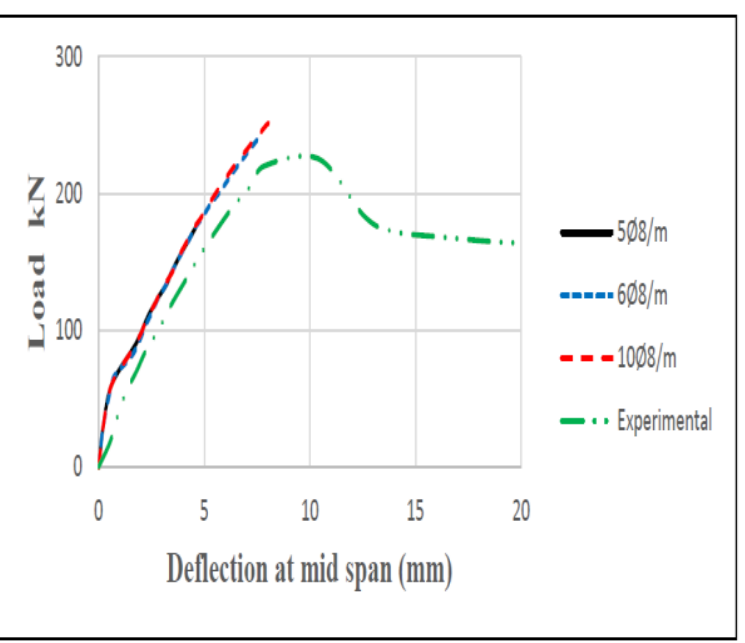

b) Depth $150 \mathrm{~mm}$

Fig. 6: Comparison between theoretical load-deflection curves with different web reinforcement and experimental.

\section{Conclusions}

Based on the experimental and theoretical studies, the following conclusions can be drawn:

1.The different types of stirrups investigated cause an increase in the maximum failure load and corresponding deflection and slightly delayed the occurring of the diagonal cracking.

2.Using welded stirrups significantly increases the shear resistance of the shallow wide beams tested. By comparing between using traditional stirrups (four branches stirrups) and welded link stirrups, it was found that using welded stirrups increased the ultimate load by about $31 \%$ and $16 \%$ compared to traditional stirrups, with thickness equal to $200 \mathrm{~mm}$ and $150 \mathrm{~mm}$ respectively.

3. The ductility of the shallow wide beam has a significant enhancement by using stirrups and more enhancement can be achieved with changing the configuration types of steel.

4. The angle of diagonal shear crack decreases by increasing the shear span-to-depth ratio.

5.The ECP-203 is conservative in ignoring the shear reinforcement contribution in the resistance of shear stress in hidden RC beams. It is recommended to re-evaluate the contribution of the shear reinforcement in ECP-203 especially for welded stirrups.

6. Welded stirrups used proofed to be an efficient shear reinforcement for wide shallow RC beams.

\section{References}

[1] R. Deivanai, and R. Sathia, "A comparative study of welded and tied shear reinforcement in beams," Journal of Chemical and Pharmaceutical JCPS, vol. 9, no. 3, pp.1535-1537, 2016.

[2 $\quad$ R. Z Al-Rousan and M. Aissa, "The effect of beam depth on the shear behavior of reinforced concrete beams externally strengthened with carbon fiber-reinforced polymer composites," Advances in Structural Engineering, vol. 19, no. 11, pp. 1769-1779, 2016.

[3] E. M. Lotfy, H. A. Mohamadien, H. Mokhtar Hassan, "Effect of Web Reinforcement on Shear Strength of Shallow Wide Beam," International Journal of Engineering and Technical Research (IJETR), vol. 2, no. 11, pp. 98-107, 2014.

[4] M. Said \& M. El-rakib, "Enhancement of shear strength and ductility for Reinforced concrete wide beams due to web Reinforcement," International Journal of Civil Engineering and Technology (IJCIET), vol. 4, no. 5, pp.168$180,2013$.

[5] M. M. Hanafy, H. M. Mohamed and N. A. B. Yehia, "On the Contribution of Shear Reinforcement in Shear Strength of Shallow Wide Beams," Life Science Journal, vol. 9, no. 3, pp. 484-498, 2012.

[6] ECP-203, Egyptian code of practice for design and construction of reinforced concrete structures. Housing and Building Research Center, Giza, Egypt, 2011. 
[7] ACI Committee 318, Building code requirements for structural concrete. American Concrete Institute, 2014.

[8] Eurocode EN 1992, "Design of concrete structures, Part 1: General rules and rules for buildings," Thomas Telford, London, 2004.

[9] CSA Committee A23.3, Design of concrete structures, CSA A23.3-04. Rexdale, Ontario, Canada: Canadian Standards Association, 2004. 